\title{
KUULEMISTILAISUUS INSTITUTIONAALISENA VUOROVAIKUTUKSENA LAPSEN HUOSTAANOTON VALMISTELUPROSESSISSA
}

Tuula-Riitta Välikoski: FT, HM, dosentti, yliopistonlehtori (emerita), Tampereen yliopisto

Tarja Pösö: YTT, professori, Tampereen yliopisto

Raija Huhtanen: HT, professori (emerita), Tampereen yliopisto

tuula-riitta.valikoski@tuni.fi;tarja.poso@tuni.fi; raija.bubtanen@tuni.fi

Janus vol. 28 (4) 2020, 323-340

a) J a II S y

Tiivistelmä

Artikkelissa tarkastellaan lapsen huostaanottoon liittyviä kuulemistilaisuuksia institutionaalisena vuorovaikutuksena. Kuulemisen tarkoitus on selvittää asianosaisten mielipide huostaanottoon ja siihen liittyvään sijaishuoltoon sijoittamiseen. Koska mielipide - suostumus tai vastustus - vaikuttaa huostaanoton päätöksentekoprosessiin, kuuleminen on vuorovaikutustilanteena tärkeä. Teoreettisen taustan luovat organisaatioviestinnän institutionaalinen teoria ja sosiokulttuurinen näkökulma. Aineistona ovat litteroidut kuulemistilaisuudet $(n=16)$, joissa ilmenevää vuorovaikutusta sekä osapuolien välisiä viestintäsuhteita analysoidaan temaattisesti.Vuorovaikutuksen tutkimuksen ohella tarkastelussa hyödynnetään oikeus- ja sosiaalityön tutkimuksen näkökulmia. Vaikka kuulemistilaisuus on virallinen, sen osapuolten väliset viestintäsuhteet asymmetriset ja asiakirjoilla siinä tärkeä rooli, sisältää tilaisuuden vuorovaikutus myös läheisyyttä ja välittämistä osoittavia viestintätekoja. Sosiaalityöntekijät eivät ohjaile asianosaisten mielipiteitä mihinkään suuntaan. Kriittiset kohdat liittyvät informaation tarjoamisen, mielipiteen ilmaisemisen ja dokumentoinnin ajoituksiin.

\section{JOHDANTO}

Vuonna 2018 pidettiin vähintään 1777 kuulemistilaisuutta sosiaalitoimessa osana lapsen huostaanoton valmisteluprosessia. Luku perustuu tietoon huostaanottojen määrästä (Lastensuojelu $2018,8)$ ja arvioon siitä, että jokaisessa huostaanottoasiassa on kuultu ainakin yhtä huoltajaa. Tosiasiallinen kuulemistilaisuuksien määrä on reippaasti suurempi, koska yhdessä huostaanottoasiassa kuultavia on useampia kuin yksi ja kuulemistilaisuus järjestetään erikseen kunkin osapuolen kanssa puhuttaneen useista tuhansista kuulemistilaisuuksista yhden vuoden aikana. Siihenkin nähden on yllättävää, että kuulemisen käytäntöjä ei ole juuri tutkittu (Helavirta, Laakso \& Pösö 2014).
Tässä artikkelissa kuulemistilaisuuksia tarkastellaan institutionaalisena vuorovaikutuksena. Kiinnostus on siinä, mitä tapahtuu sosiaalityöntekijöiden, lasten, vanhempien ja muiden välisissä kohtaamisissa, joiden tarkoitus on saada esiin vanhempien (nimenomaan huoltajien) ja lapsen (erityisesti 12-17 -vuotiaan) mielipiteet huostaanotosta ja sijaishuoltoon sijoittamisesta. Kuuleminen on pakollinen osa huostaanoton valmistelua (lastensuojelulaki 417/2007, 42 S). Mielipiteet vaikuttavat huostaanottoasian päätöksentekoprosessiin: jos asianosaiset suostuvat sosiaalityöntekijöiden ehdotukseen huostaanotosta ja sijaishuoltoon sijoittamisesta, asiasta päättäminen kuuluu sosiaalihuollon johtavalle viranhaltijalle. Jos yksikin asianosaisista vastustaa huostaanottoa 
tai sijaishuoltoon sijoittamista taikka molempia, päätösvalta asiasta on hallinto-oikeudella (lastensuojelulaki 43 S). Koska kuulemistilaisuudessa ilmaistu mielipide on merkittävä tekijä huostaanottoprosessissa, ei ole samantekevää, millainen vuorovaikutustilanne kuuleminen on ja miten se tukee mielipiteen esittämistä. Kuulemistilaisuuden erityistä kiinnostavuutta lisää se, että siinä ilmaistuista mielipiteistä riippuen päätös huostaanotosta voidaan tehdä sosiaalityössä ilman tuomioistuinkäsittelyä, mikä on poikkeuksellinen käytäntö kansainvälisesti (Burns, Pösö \& Skivenes 2017).

Artikkelissa analysoidaan kuulemistilaisuuksissa ilmenevää osapuolien välistä vuorovaikutusta. Koska lainsäädäntö asettaa kuulemiselle määrätyt puitteet ja koska kuuleminen on osa sosiaalityöntekijöiden vetämää lastensuojeluprosessia, kuvataan ensin lyhyesti kuulemisen tehtäviä lastensuojelussa. Sen jälkeen täsmennetään vuorovaikutuksen tarkastelussa tarvittavia teoreettisia käsitteitä. Empiiristen havaintojen pohjalta esitetään tulkintoja paitsi siitä, mitä kuulemistilaisuus on institutionaalisena vuorovaikutuksena, myös siitä, miten vuorovaikutus toteuttaa tilaisuudelle asetettuja odotuksia asianosaisten mielipiteen selvittämiseksi. Pohdintaa tukee kirjoittajaryhmän monitieteisyys: ydinanalyysi on tehty vuorovaikutuksen ja viestinnän tutkimuksen näkökulmasta, mutta taustoituksessa ja loppupohdinnoissa hyödynnetään myös oikeustieteen ja sosiaalityön tutkimuksen näkökulmia ${ }^{1}$.

\section{KuULEMINEN LASTENSUOJELUSSA}

Vakiintunut käytäntö on, että sosiaalityöntekijät vastaavat kuulemistilaisuuden järjestämisestä ja itse kuulemisesta osana huostaanottoasian valmistelua. Huostaanottoa valmisteleva prosessi on usein monivaiheinen ja pitkäkestoinen. Lapsen asioista vastaava sosiaalityöntekijä on saattanut työskennellä lapsen ja perheen kanssa jo pitkään. Pekkarisen (2016) tutkimuksessa lasten keskimääräinen asiakkuushistoria oli viisi vuotta ennen huostaanottoa. Pisimmillään lapsen asiakkuus oli kestänyt 15 vuotta, lyhyimmillään kuukausia. Edeltävään prosessiin on sisältynyt avohuollon tukitoimia ja sosiaalityötä, ehkä kiireellisiä sijoituksiakin. Tuona aikana on selvitetty lapsen ja perheen tilannetta ja tuettu muutoksia lapsen ja perheen tilanteessa. Kuulemistilaisuudessa muutostyöpainotus muuttuu pyrkimykseksi selvittää huoltajien ja lapsen mielipiteet asiaan, kun sosiaalityöntekijä viranomaisena arvioi, että huostaanoton kriteerit täyttyvät ja lapsen sijoittaminen sijaishuoltoon on perusteltua. Lapsi ja vanhemmat ovat eri tavoin mielipiteineen ja näkemyksineen osallistuneet neuvotteluihin koko lastensuojeluprosessin ajan, kuten lastensuojelulaki ja sosiaalityön ammatilliseettinen asiakaslähtöisyyden korostus (Lonne ym. 2016) edellyttävät. Kuulemistilaisuudessa mielipiteitä kuullaan erityisessä oikeudellisessa tarkoituksessa (ks. esim. Toivonen \& Pollari 2018).

Oikeudelliselta kannalta kuuleminen on tärkeä ennakollisen oikeussuojan tae $\mathrm{ja}$ asianosaisen menettelyllinen oikeus, josta säädetään jo perustuslaissa (PL 21 S). Se turvaa tasapuolisuutta ja vastavuoroisuutta hallinnollisessa 
päätöksenteossa. Tasapuolisuus edellyttää asianosaisen oikeutta saada tietoonsa periaatteessa kaikki se informaatio, joka on päätöksen tekevän viranomaisen käytössä, sekä oikeutta lausua käsityksensä tuon informaation johdosta ja esittää muutoinkin mielipiteensä asiassa. Viranomaisen tulee puolestaan punnita esitettyä mielipidettä ja arvioida, miten se mahdollisesti vaikuttaa annettavaan ratkaisuun. Kuulemisen oikeusturvatehtävä korostuu asioissa, jotka voivat vaikuttaa epäedullisesti asianosaisen asemaan. Lapsen huostaanotto on yksi tällainen asia. Toissijaisesti kuuleminen palvelee hallintoasian selvittämistä,josta päävastuu on viranomaisella.

Hallintolain (434/2003, 34 \$) mukaan asianosaiselle on ennen asian ratkaisemista "varattava tilaisuus lausua mielipiteensä asiasta sekä antaa selityksensä sellaisista vaatimuksista ja selvityksistä, jotka saattavat vaikuttaa asian ratkaisuun". Asianosaista on informoitava kuulemisen tarkoituksesta ja hänen oikeuksistaan menettelyssä. Asiakirjoihin tutustumista ja selvityksen antamista varten tulee varata "asian laatuun nähden riittävä määräaika", josta on ilmoitettava kuultavalle (hallintolaki 33 S). Mitä monimutkaisempi asia on ja mitä enemmän asiakirjoja siihen liittyy, sitä pidempi määräaika yleensä vaaditaan. Asianosaisen tiedonsaantioikeus ulottuu myös salassa pidettäviin asiakirjoihin eräitä harvoja poikkeuksia lukuun ottamatta. Asiakirjoihin tutustuminen ei edellytä asianosaisen pyyntöä, vaan viranomaisen tulee varata siihen tilaisuus oma-aloitteisesti.

Hallintolaki lähtee siitä, että kuuleminen tapahtuu kirjallisesti. Suullinenkin kuuleminen on mahdollinen, ja silloin viranomainen vastaa esiin tulleiden asioiden kirjaamisesta. Jotta kuuleminen olisi tehokasta, se on ajoitettava niin, että asianosaisen esittämät käsitykset voivat vielä vaikuttaa annettavaan ratkaisuun. Liian aikaisin kuulemista ei pidä toisaalta järjestää, sillä ennen mielipiteen esittämistä asianosaisen on voitava tutustua kaikkiin ratkaisuun mahdollisesti vaikuttaviin asiakirjoihin. Tarvittaessa kuuleminen on uusittava. (Esim. Kulla 2018, 265-281; Mäenpää 2018, 460-471.)

Kuulemisen tehtävä huostaanottoasiassa ei rajoitu vain huoltajien ja 12 vuotta täyttäneen lapsen mielipiteen selvittämiseen. Lastensuojelulain mukaan kuultavia henkilöitä ovat muutkin kuin ne, jotka voivat tehokkaasti vastustaa huostaanottoa, eli edellä mainittujen lisäksi lapsen (huollosta erotettu) vanhempi, muu lapselle läheinen henkilö (esim. isovanhempi) ja 12 vuotta nuorempi lapsi, jonka puhevaltaa käyttää tosin huoltaja tai lapselle määrätty edunvalvoja.

\section{KUULEMISTILAISUUS VIESTINTÄTILANTEENA} JA INSTITUTIONAALISENA VUOROVAIKUTUKSENA: SOSIOKULTTUURINEN NÄKÖKULMA

Vaikka kuulemisesta ei ole kattavaa yleiskuvaa, tutkimamme asiakirjat, sosiaalityöntekijöiden haastattelut ja kuulemistilaisuusaineisto viittaavat siihen, että huostaanottoa koskevat kuulemiset järjestetään käytännössä lähes aina suullisina. Kuulemistilaisuus on tällöin henkilöiden välinen, kasvokkain tapahtuva viestintätilanne, jossa asioita selvitetään osapuolien välisessä viestintäsuhteessa välittömässä vuorovaikutuk- 
sessa. Vuorovaikutussuhteeseen tullaan ja sitä lähtökohtaisesti luodaan osallistujien asioiden tilasta ja osapuolien välisestä suhteesta muodostamien käsitysten pohjalta. Nämä käsitykset sekä ymmärrys itse kuulemistilaisuudesta perustuvat osapuolien aiempaan, huostaanottokuulemisissa usein pitkäkestoiseenkin yhteistyöhön ja muokkaavat tilaisuuden vuorovaikutusta. Myös instituutio tulee vuorovaikutuksessa havaittavaksi osallistujien erilaisissa viestintäteoissa, joilla puolestaan luodaan ja ylläpidetään instituution käytänteitä (Pennanen 2018, 20; Lammers \& Barbour 2006, 363-364). Näin säädösten ohjaama, käsityksissä abstrakti kuuleminen rakentuu konkreettiseksi kuulemistilaisuudeksi osapuolien välisessä vuorovaikutuksessa. Jokainen, yksittäinen kuulemistilaisuus on osaltaan "pala" lastensuojelua per se.

Kuvattu käsitys vuorovaikutuksesta edustaa ns. sosiokulttuurista näkemystä viestinnästä,jonka keskeisenä ajatuksena on toimijoiden vuorovaikutuksessaan tuottama ja erilaisten viestintätekojen rakentama yhteinen viestintäkulttuuri (Craig 2007).Viestintä ja vuorovaikutus taas sitoutuvat toisiinsa Baxterin (2010) mukaan siten, että viestintä nähdään vuorovaikutteisena merkityksenantoprosessina, jossa viestit ovat sidoksissa toisiinsa.Tällöin toimijoiden merkityksenanto on enemmän sosiaalista kuin kognitiivista, eli se tapahtuu viestintätekojen ja -käytänteiden vuorovaikutuksena eikä niinkään toimijoiden tiedollisina prosesseina (Gerlander \& Isotalus 2010, 6). Sosiaalisen merkityksenannon rinnalla voidaan korostaa toimijoiden kognitiivisia prosesseja. Tällöin vuorovaikutuksen nähdään käynnistyvän kunkin toimijan informaation proses- soinnista, joka ei tuota kuitenkaan automaattisesti merkityksiä jakavaa vuorovaikutusta toimijoiden välille. Myös Pearcen ja Kearneyn (2004) vuorovaikutukselta edellyttämä toimijoiden toisiinsa vaikuttaminen, vain toistensa viesteihin reagoimisen sijasta, saattaa olla vähäistä.

Institutionaalista keskustelua käydään instituution asettamana, usein instituution ohjaamin menettelyin, tehtävin, tavoittein, säätelemin kokoonpanoin ja roolituksin. Kokoonpano koostuu erilaisista asiantuntijoista sekä maallikoista, kuten asianosaisista tai asiakkaista (vrt. Hall ym. 2014; Ruusuvuori ym. 2001). Keskustelua käydään usein kirjallisten asiakirjojen pohjalta, jotka lisäävät vuorovaikutukseen ei-inhimillisen toimijuuden. Toimijuus syntyy asiakirjojen lukemisesta ja niiden käsittelystä eri tavoin. Näin asiakirjat ovat vuorovaikutuksessa itsenään, mutta myös osallistujien puheenvuoroissa (Laapotti 2018). Tämä on tavanomaista myös sosiaalityössä (Günther 2015; Räsänen 2015). Osallistujien viestintäsuhde käynnistyy instituution toimesta, kehittyy instituution luomassa toimintakehyksessä ja saa vaikutteita siitä, miten ja millaisin viestintäteoin instituutiota luodaan ja ylläpidetään heidän keskusteluissaan. Näin ollen myös osallistujien välinen vuorovaikutus on institutionaalista.

Institutionaaliselle keskustelulle on tyypillistä, että sen menettelyllinen eteneminen on ennustettavissa. Oikeudellisessa kontekstissa tämä on nähty maallikon yhtenä oikeusturvan takaajana (Ervasti \& de Godzinsky 2014; Välikoski \& Ala-Kortesmaa 2014). Instituution osoittama menettely, kokoonpano ja roolitus taustoittavat asiantunti- 
javaltaa, joka näkyy myös keskustelussa asymmetrisena viestintäsuhteena asiantuntijan ja maallikon välillä. Tällöin viestintä on epätasapainoista, koska osallistumisen mahdollisuus on sidottu sovittuun menettelylliseen etenemiseen tai puhujan rooliin ja statukseen.

\section{TUTKIMUSTEHTÄVÄ, AINEISTO JA MENETELMÄ}

Artikkelin tavoitteena on kuvata ja ymmärtää kuulemistilaisuutta institutionaalisena vuorovaikutuksena ja osana lapsen huostaanottopäätöksen valmistelua. Keskiössä on sosiaalityöntekijän ja kuultavan viestintäsuhde. Tavoitteeseen edetään vastaamalla seuraaviin kysymyksiin:

1. Millaista vuorovaikutusta sisältävien vaiheiden ja millaisten sosiaalityöntekijän viestintätekojen avulla edetään kohti mielipiteiden ilmaisemista?

2. Miten instituution asettamat tavoitteet (tiedon välittäminen, vapaa mielipiteen ja tahdonilmaisu) näkyvät vuorovaikutuksessa ja sosiaalityöntekijän viestintäteoissa?

3. Miten institutionaalisuutta edustavat asiakirjat liittyvät vuorovaikutukseen ja rakentavat siinä ei-inhimillistä toimijuuttaan?

Tutkimusaineisto muodostuu 16 kuulemistilaisuudesta kolmessa Suomen kunnassa. Niistä 11:ssa kuultiin vain yhtä vanhempaa (8 äitiä ja 3 isää). Lasta $(12-17 \mathrm{v}$.$) kuultiin yksin kolmessa ja$ äidin tai omahoitajan kanssa kahdessa tilaisuudessa. Kaikissa tilaisuuksissa oli läsnä kaksi sosiaalityöntekijää, ja tutkija osallistui kuuteen tilaisuuteen. Mui- ta henkilöitä kuten tukihenkilöitä tai oikeudellisia avustajia ei osallistunut tilaisuuksiin. Kuulemistilaisuudet toteutettiin yhtä lukuun ottamatta sosiaalitoimen tiloissa, ja niiden kesto vaihteli 20 minuutista 1,5 tuntiin. Tilaisuuksista kaksi päättyi vastustukseen ja 14 suostumuksen ilmaisemiseen ${ }^{2}$. Kuulemistilaisuudet on ääninauhoitettu ja kuultuna litteroitu sanatarkasti.

Kuulemistilaisuus huostaanottoasiassa on viestintätilanteena hyvin yksityinen, sensitiivinen ja emotionaalinen, eikä tutkimusaineiston kerääminen siihen lähtökohtaisesti kuulu ${ }^{3}$. Luvat aineistonkeruuseen saatiin jokaiselta tutkimukseen osallistuneelta kunnalta ja erikseen niiden sosiaalityön tiimeiltä, tutkimus kävi läpi eettisen ennakkoarvioinnin ja luvat jokaiselta kuultavalta pyydettiin erikseen. Ensimmäisessä vaiheessa sosiaalityöntekijät kysyivät kuulemistilaisuuteen tulevilta, suostuvatko nämä tutkijan läsnäoloon tai tilaisuuden äänitallentamiseen. Jos alustava suostumus saatiin, se varmistettiin vielä kuulemistilaisuudessa. Ei voida arvioida, kysyivätkö sosiaalityöntekijät lupaa vain tietyntyyppisiltä perheiltä tai antoivatko vain tietynlaiset vanhemmat tai lapset suostumuksensa. Tutkijan läsnäolo ei välttämättä vaikuttanut kuultavien toimintaan tilaisuudessa, sillä myös toinen kuulemistilaisuuden sosiaalityöntekijöistä saattoi olla kuultaville ennestään tuntematon. Tutkijan vaikutusta sosiaalityöntekijöiden toimintaan on vaikea arvioida. Se, että taltiointeja kertyi tutkimusprosessin aikana odotettua enemmän, kertonee siitä, että sosiaalityöntekijät omalta osaltaan pyrkivät tukemaan tutkimusaineiston keruuta. Tutkimusaineisto on määrällisesti pieni mutta ottaen huomioon tilaisuuksien 
sensitiivisen luonteen ja aihetta koskevan aiemman tutkimuksen puutteen, se tarjoaa joka tapauksessa ainutkertaisen näköalan kuulemistilaisuuksien vuorovaikutukseen.

Vuorovaikutusta tarkastellaan artikkelissa sosiaalityöntekijöiden sanallisten, litteroitujen viestintätekojen analyysin pohjalta. Analyysiyksikkönä on puheenvuoro eli yhden henkilön yhtäjaksoinen äänessä olo kerrallaan. Yhdestä tai useammasta tehtävään $\mathrm{ja} /$ tai viestintäsuhteisiin liittyvästä puheenvuorosta syntyy puolestaan viestintäteko. Analyysin aluksi sosiaalityöntekijöiden sanallisten viestintätekojen määrä (prosenttiosuudet) suhteessa keskustelun kestoon laskettiin. Analyysimenetelmänä on laadullinen, temaattinen sisällön analyysi (Mayan 2009), jota ohjasi kolme tutkimuskysymyksiin perustuvaa teemaa: vuorovaikutuksen funktiot, vuorovaikutuksen sisällöt ja asiakirjojen ei-inhimillinen toimijuus. Vuorovaikutuksen funktiot luokiteltiin kuulemistilaisuuden etenemisen kautta, ja sisältöjen luokittelussa hyödynnettiin Balesin (1950) IPA analyysikehystä (ks. myös Pennanen 2018) sovellettuna tähän ammatilliseen kontekstiin, jossa informaation välittäminen ja kuultavan mielipiteiden ilmaisun mahdollistaminen on keskeistä. Koska IPA:n mukaisissa viestintäteoissa on myös tuen elementtejä, niitä analysoitiin tässäkin aineistossa. Tuen muodot luokiteltiin Burlesonin (2009) jaottelun mukaisesti informatiiviseen, instrumentaaliseen ja emotionaaliseen tukeen. Viestintäteoista tulkittiin myös niiden vaikutusta kuultavan mielipiteen selvittämiseen. Tulkinnassa hyödynnettiin Galvinin ja
Cooperin (2000) ymmärrystä muun muassa viestintäsuhteiden yhteydestä keskusteluosallistumiseen. Ei-inhimillisen toimijuuden rakentumista analysoitiin asiakirjojen lukemisena ja niistä puhumisena. Vuorovaikutuksen funktiot ja sisällöt lomittuvat yhteen ja taustoittavat luonnollisesti kaikkia tuloksia, mutta artikkelissa tulokset esitellään kolmen teeman - vuorovaikutuksen funktioiden ja kuulemistilanteen rakenteen, viestintätekojen, ja ei-inhimillisen toimijuuden - mukaisessa järjestyksessä.

\section{Tulokset}

Vuorovaikutuksen funktiot ja kuulemistilaisuuden rakenne

Kuulemistilaisuuksien vuorovaikutuksen funktiona oli käynnistää tilaisuus, selvittää asiaa yhdessä kuultavan kanssa sekä päättää tilaisuus mielipiteen dokumentointiin. Vaikka instituutio ei ole antanut tilaisuudelle menettelyohjeita, kuulemistilaisuuksien rakenne muodostui keskenään samanlaisista mutta erilaisia viestintätekoja sisältävistä vuorovaikutuksen vaiheista. Kuultavalle kerrottiin lähes aina tilaisuuden alussa sen tarkoitus ja lain asettamat vaatimukset. Tilaisuuden menettelyllistä etenemistä ei sen sijaan selostettu erikseen. Eniten aikaa käytettiin asian selvittämiseen eli sosiaalitoimen ehdotuksen esittelyyn ja siihen liittyvien asiakirjojen käsittelyyn. Tilaisuus päättyi allekirjoituksiin ja jatkotoimenpiteiden toteamiseen. Näitä funktioita kuvataan seuraavassa tarkemmin. 
Taulukko 1. Institutionaalinen vuorovaikutus kuulemistilaisuudessa.

\begin{tabular}{|l|l|l|l|l|}
\hline Vaiheet & Funktiot & Sisällöt & Viestintäteot & $\mathbf{\%} / \mathbf{k e s t o}$ \\
\hline I & käynnistys & $\begin{array}{l}\text { tilaisuuden } \\
\text { tarkoitus ja laki }\end{array}$ & $\begin{array}{l}\text { informaation } \\
\text { anto ja pyyntö }\end{array}$ & $60 \%$ \\
\hline II & $\begin{array}{l}\text { tiedon välitys ja } \\
\text { asian selvitys }\end{array}$ & $\begin{array}{l}\text { asiakirjat ja } \\
\text { sosiaalitoimen } \\
\text { ehdotus }\end{array}$ & $\begin{array}{l}\text { tuen anto ja } \\
\text { ymmärryksen } \\
\text { osoitus }\end{array}$ & $25 \%$ \\
\hline III & $\begin{array}{l}\text { päätös: mielipide } \\
\text { ja sen } \\
\text { dokumentointi }\end{array}$ & $\begin{array}{l}\text { allekirjoitus ja } \\
\text { jatkotoimet }\end{array}$ & $\begin{array}{l}\text { epäselvyyksien } \\
\text { selvitys }\end{array}$ & $15 \%$ \\
\hline
\end{tabular}

Ensimmäinen vuorovaikutuksen vaihe, funktiona käynnistää tilaisuus, alkoi lähes aina sosiaalityöntekijän tervehdyksillä sekä tilaisuuden tarkoituksen ja tehtävän esittelyllä. Vain kolmessa tilaisuudessa 16:sta kyseltiin kuulumisia tai puhuttiin jostakin tilanteeseen liittyvästä asiasta, kuten huoneen lämpötilasta tai kuultavan flunssasta. Vain kolmessa tilaisuudessa läsnäolijat esiteltiin ja kuultavalle kerrottiin, kuka ja miksi toinen sosiaalityöntekijä on paikalla. Jos perheen lapsi on otettu huostaan aiemmin tai kuulemistilaisuuksia on pidetty lapsen asiassa aikaisemminkin, tilanne on kuultavalle tuttu. Pääsääntöisesti se oli kuultaville kuitenkin tilanteena uusi. Uusi tilanne voi aikaansaada jo sellaisenaan formaaliseen tilanteeseen liittyvää jännittyneisyyttä, joka ilmenee erityisesti tilanteen alussa ja vaikuttaa osapuolten väliseen vuorovaikutukseen (vrt. Välikoski, Saranpää, Paulanto \& Kulmakorpi 2017). Yllättävästi asia tuotiin ääneen esiin vain yhdessä kuulemisessa.

Äiti: Tää on mulle ihan uus asia, mä en oo koskaan ennen ollu tämmösessä.

ST2: Nii tämmösessä tilanteessa, joo.

ST1: Joo aivan. Eikä tän oo tarkotuskaan olla jäykkää, mut meil on siis tosiaan täal tämmönen paperi mikä pyyetään siuta sitte täyttämään lopuks, mut että sitä ennen siul on mahdollisuus saaha tietoo tästä huostaanotosta, me ollaan tästä aika paljon neuvottelussa keskusteltukin. Miten siul on kokemus et ootko saanu riittävästi tietoo? Äiti: Olen, mut täs on vähä semmosii... ST1: Koska mie aattelen et nyt on tosi tärkee kysyy niit kysymyksiä jos on semmosia. Äiti: Juu, että...

ST1: Ei oo tyhmiä kysymyksiä aiheeseen liittyen. (K1)

Keskustelu käynnistyi äidin sanoittamasta asiasta, minkä jälkeen sosiaalityöntekijä osoitti ymmärrystä ja lisäsi siten vuorovaikutuksen sujuvuutta. Muutamassa kuulemistilaisuudessa sosiaalityöntekijä saattoi itse viitata tilanteen virallisuuteen osana alkupuheenvuoroaan esimerkiksi seuraavasti:

ST1: eli tosiaan, virallinen kuulemistilaisuus, jossa sun mielipide kuullaan ja sit me laitetaan se tohon pöytäkirjaan allekirjoitetaan kaikki sitten et, sun mielipide on kuultu ja nyt, onks sul ekaks jotain kysyttävää vai ...? (K6)

Toinen vuorovaikutuksen vaihe, funktiona välittää tietoa ja selvittää asiaa, toteutettiin kuulemistilaisuuksissa eri tavoin. Asiaa selvitettiin joissakin kuulemisissa rutiininomaisesti, jolloin asiakirjoja käytiin lävitse vain satunnaisesti eikä kuultavaa juuri rohkaistu 
niitä lukemaan tai kommentoimaan. Vuorovaikutuksessa korostuivat tehtävän hoito ja kuultavan mielipiteen kirjaaminen. Kuulemistilaisuus oli kestoltaan lyhyt. Selvitystehtävää hoidettiin myös käymällä asiakirjoja lävitse yhdessä kuultavan kanssa ja kehottamalla tätä lukemaan niitä.Viestintätekoina oli runsaasti epäselvyyksien selvittämistä ja suhdesanomina tuen ja ymmärryksen osoittamista. Useimmin asiaa selvitettiin tällä tavalla. Seuraava aineisto-ote, jossa kuultiin äitiä ja lasta yhtä aikaa, on tästä esimerkki.

ST1:Joo, eli ne ois oikeestaan ne litteet. Sit se mistä puhuin tossa aulassa, et se lääkärin tarkastuksen tai yhteenveto oli tarkotus myös olla liitteenä, mut nyt sitä ei oo, ett se tulee sieltä jälkikäteen. Tietenkin teillä on ne kaikki oikeus saada. Annanks mä teille nää valmistelupäätökset, haluutteks te lukee?

Äiti: Siis luetaaks me (äiti ja lapsi yhdessä) nää eka?

ST1: Nyt saa lukee. Te ette saa niitä mukaanne, että saatte sitte vasta.

Äiti: Okei, mut ääneen ei tartte lukee?

ST1: Ei tarvii.

ST2: Ei oo oikeinlukuharjoitus vaan.

ST1: Me hiljennytään ja te saatte rauhassa lukee. (K5)

Aineistosta löytyi myös muutama tapaus, jossa sosiaalityöntekijä esitteli asiakirjoja, luki niitä ja kokosi lopuksi yhteen, miksi nykyisessä huostaanottotilanteessa oltiin. Viestintätekoina oli tällöin informaation pyytämistä, epäselvyyksien selvittämistä sekä suhdesanomina tuen ja ymmärryksen osoittamista. Kuulemisen kesto oli pitkä. Seuraava aineistoleike kuvaa tätä selvitystapaa.
ST1: Okei, haluutsä et mä vähän luen tai käytäs läpi että, mitä tääl (asiakirjoissa) on, vai?

Isä: Tee semmonen hyvä yhteenveto. Tarvi kaikkee ..

ST1: (nauraa)

Isä: Joka pilkkuu sielt, pistää.

ST1: Eli tääl on nyt sit...

Isä: Silleen suurin piirtein missä mennään ni se riittää mulle.

ST1:Juu. Eli täs on ensiks listattu näit X:n (lapsen) sijotuksii. Eli täs nyt sit vuodenvaihteen jälkeen ni on, useampi perättäinen sijotus ... (K6)

Aineistossa kuultiin viittä lasta. Vuorovaikutus ei tällöin juuri poikennut yleisestä vuorovaikutuksellisten vaiheiden linjasta, mutta asiakirjoja käsiteltäessä sosiaalityöntekijän viestintätekoina oli lapsen ymmärryksen varmistaminen erityisesti tyyliin "onko tämä sinulle selvää?" tai "kysy ihmeessä, jos on jotain". Lapselle myös perusteltiin täytettävän lomakkeen helppoutta "tää on tällainen ihan helppo lomake".

Vuorovaikutuksen viimeinen vaihe, funktiona kuulemistilaisuuden päättäminen, sisälsi kuultavan mielipiteen ilmaisemisen ja sen dokumentoinnin ("ruksit" vastustamisesta tai vastustuksen puutteesta, niiden mahdollinen perustelu ja allekirjoitus). Siksi se, mitä tapahtuu vuorovaikutuksellisesti ennen mielipiteen dokumentointia, on olennaista tilaisuuden tarkoituksen toteutumisen kannalta. Huostaanoton oikeusvaikutuksista kerrottiin yleisesti seitsemässä kuulemistilaisuudessa ennen "ruksien" merkitsemistä ja allekirjoituksia. Esimerkiksi lapsilisän maksamisen muutoksia selviteltiin neljässä tapauksessa. Kahdessa kuulemistilaisuudessa kuultava itse kysyi "ruksien" 
merkinnän jälkeen päätöksen seurauksista, ja yhdessä tilaisuudessa kuultava kysyi allekirjoitusten jälkeen, miten mahdollinen huostassa pidon lopettaminen tapahtuu. Lomakkeen täyttämisen ja allekirjoitusten jälkeen kerrottiin lähes aina, mitä lapsen arjessa tapahtuu seuraavaksi esimerkiksi sijoituspaikan tai koulun osalta ja miten asia etenee. Lähes joka toisessa kuulemistilaisuudessa juteltiin lopuksi vielä "niitä näitä" esimerkiksi samankokoisista kengistä tai kesäsuunnitelmista.

Missään kuulemistilaisuuden vaiheessa sosiaalityöntekijä ei juuri keskeyttänyt kuultavaa eikä palauttanut selvästi aiheesta poikkeaviakaan puheenvuoroja aiheeseen. Sosiaalityöntekijän viestintäteoista ei myöskään käynyt ilmi, että hän osoittaisi eriävää mielipidettään tai kommentoisi mitenkään kuultavan valintaa edes silloin, kun tämä päätyi vastustamaan huostaanottoa, sijoituspaikkaa tai molempia.

Viestintäteot kuultavan mielipiteen selvittämisen näkökulmasta

Sosiaalityöntekijän viestintätekoja ohjaavat sekä tiedon välittämisen että kuultavan mielipiteen selvittämisen tavoitteet. Näihin tavoitteisiin pyrittiin tutkitussa aineistossa antamalla ja pyytämällä informaatiota $(60 \%)$, selvittämällä epäselvyyksiä (15\%) sekä tukemalla ja osoittamalla ymmärrystä eri tavoin (25\%). Kaikki Burlesonin (2009) erittelemät tuen muodot näkyivät aineistossa aina emotionaalisesta tuesta instrumentaaliseen tukeen, kuten esimerkiksi nenäliinan, mehun tai vertaisryhmien tapaamisten tarjoamiseen. Eniten keskusteluaikaa käytettiin kai- kissa tapauksissa asiakirjojen läpikäyntiin.

Sosiaalityöntekijä voi hoitaa tiedon välittämistehtävää omilla viestinnällisillä valinnoillaan, mutta mielipiteen selvittämisessä tarvitaan myös kuultavan viestintätekoja. Kuultava voi kertoa mielipiteensä huostaanotosta ja sijaishuoltoon sijoittamisesta monitulkintaisesti, tai mielipidettä on vaikea muodostaa asian henkilökohtaisen merkityksellisyyden vuoksi. Näin ollen mielipiteen suora kysyminen ei välttämättä tuota vastausta. Seuraavassa kuvataan, mitkä muut viestinnälliset teot, kuten samojen havaintojen jakaminen, osallistumisen rohkaisu ja ymmärryksen osoittaminen, liittyvät toimivan viestintäsuhteen rakentumiseen ja ovat yhteydessä keskusteluosallistumiseen.

Joissakin kuulemisissa sosiaalityöntekijän viestintätekoina oli kuullun kommentointi, kun taas joissakin muissa tätä tapahtui vähemmän. Kommentointiin sisältyi usein myönteinen palaute kuultavan toiminnasta, ja sillä myös jaettiin samoja havaintoja.

Äiti: Joo, mä olin kans silleen, että meinas happi loppuu, mut mä sain iha hienosti kyllä hoidettuu, että ...lapset pelästy tietenki, että äiti mikä on, hei, onko kaikki hyvi, onko kaikki hyvin.

ST1: Nii, voi että. Mut hyvä ku sie nyt tulit paikalle vaikka lapsesi siellä vielä miettii, ja tosiaan myö siun kans vielä siinä perjantaina. Ai kamala, ai kamala siul on raskas toi (flunssa). (K2)

ST: Hienosti jaksoit lukea (lapsi) paljon tekstiä, mutta hyvä että luit niin tiedät mihin otat kantaa. (K7) 
Osallistumaan rohkaisua osoitettiin pääasiassa suoraan siihen kehottamalla. Rohkaisua saattoi tapahtua myös osoittamalla samanmielisyyttä kuultavan sanomaan. Näin tapahtui kuulemisessa (K5), jossa lapsi oli ilmoittanut puhuvansa "äidin kautta” äidin kanssa, mutta päätyi kuitenkin itse puhumaan kuultavana:

ST1: Siis mulla on sama mieli et edelleen tapahtuu asioita, et lastensuojelu ei vieläkään oo ehkä....miten sanois, riittävän modernia, et vieläkin ehkä vaikka yritetään kouluttaa tosi paljon, mut se ymmärrys tämmösillä pienillä asioilla et millai viestitään siellä (perhekodissa) esimerkiks nuoren kanssa. Niin sillä on tosi paljon merkitystä sille nuorelle, et millä tavalla sitä nuorta kohdellaan, sillä on tosi iso merkitys sille nuorelle....

Äiti: Et jos nuori on alakulonen, äree, siel ajatuksis ja muuta niin ku X:llä (lapsella) on tässä ollukki ja varsinki sillo ku niit lomii ei oo saanu olla tai muuta, niin kyl mä oon sitä mieltä et kyl se ohjaajaki vois siin kohtaa kattoo peilii.

ST1: Ja ohjaajien pitäis kyllä sietää, se on heidän työtään ja heidän

kuuluu ...

Lapsi: Eikä niistä (lääkäriaika) ilmoteta mullekkaa. (K5)

Samassa kuvauksessa sosiaalityöntekijä osoitti myös ymmärrystä, sillä hän vahvisti äidin sanoman ottamalla kriittisesti kantaa ohjaajien toimintaan. Ehkä juuri tämä sosiaalityöntekijän viestintäteko koettiin merkitykselliseksi, sillä näiden puheenvuorojen jälkeen lapsi käytti ensimmäisen puheenvuoronsa ja osallistui keskusteluun. Yleisestikin ymmärrystä osoitettiin kuultavan henkilökohtaista tilannetta kohtaan.
Samojen havaintojen jakaminen, osallistumaan rohkaisu sekä ymmärryksen osoittaminen ovat viestintätekoja, joiden voidaan tulkita liittyvän toisiinsa ja myös lähentävän asiantuntijan ja maallikon välistä viestintäsuhdetta. Viestintäsuhteen läheisyys helpottaa osallistumista ja mielipiteen ilmaisua (Galvin \& Cooper 2000), joten viestintäteot myös edesauttavat kuultavan mielipiteen selvittämistä.Viestintätekojen, joilla puhujaa ei keskeytetä eikä palauteta aiheeseen, voidaan tulkita myös rohkaisevan välillisesti osallistumaan ja lisäävän mahdollisuuksia mielipiteen ilmaisuun. Nämä piirteet vahvistavat kuultavan viestinnällistä itsemääräämisoikeutta. Läheinen ammatillinen viestintäsuhde (Gerlander \& Isotalus 2010) voisi myös häiritä kuultavan itsemääräämisoikeuden käyttämistä ja tuottaa tilanteen, jossa sosiaalityöntekijä vaikuttaisi kuultavan mielipiteisiin esittämällä omia näkemyksiään. Tähän viittaavaa sosiaalityöntekijän viestintäkäyttäytymistä ei esiintynyt tutkitussa aineistossa.

Sosiaalityöntekijän edellä kuvatut viestintäteot voidaan liittää myös suhteen jännitteisiin, kuten jännitteisiin etäisyyden ja läheisyyden välillä (Baxter 2010). Samojen havaintojen jakamisen voidaan tulkita kuvaavan suhteen läheisyyttä, kun taas osallistumiseen rohkaisemattomuus voi lisätä suhteen etäisyyttä. Samojen havaintojen jakaminen ja ymmärryksen osoittaminen ovat toisaalta tulkittavissa myös ammatilliseksi itsestä kertomiseksi. Teoilla paitsi tuotetaan läheisyyden ja tuttavallisuuden vaikutelmaa myös osoitetaan kuuntelemista sekä tarjotaan mahdollisuutta samaistua kuultavan tilanteeseen. Asiantuntija voi näin jakaa ääneen saman havainnon tai huomion maallikon 
kanssa, tehdä hänet siten suhteessa huomatuksi ja aikaansaada merkityksellisyyden kokemuksia kaikille osapuolille. Viestintäsuhteet eivät tässä asiantuntija-maallikkovuorovaikutuksessa ole muutenkaan korostetun asymmetrisia, joten kuulemistilanteen professionaalinen vuorovaikutus ei edusta tyypillistä institutionaalista vuorovaikutusta (Välikoski \& Ala-Kortesmaa 2014).

Vaikka viestintäsuhde sosiaalityöntekijän ja kuultavan välillä ei vaikuta kuulemistilaisuudessa korostetun asymmetriselta eikä keskustelua käydä instituution määräämin menettelyin, asiantuntijavalta näkyy tapaamisessa: sen läsnäolo ja kuultavan henkilökohtainen suhde käsiteltävään asiaan muokkaavat vuorovaikutusta asymmetriseen suuntaan. Tähän vaikuttaa myös se, ettei tilaisuuden menettelyllistä etenemistä esitelty kuultavalle erikseen. Vuorovaikutussuhteen asymmetrisyyttä korostaa myös asiantuntijoiden laatimien asiakirjojen suuri määrä sekä konkreettisesti että puheenvuorojen kohteena.

\section{Asiakirjojen luoma ei-inhimillinen toimi- juus}

Cooren (2018) määrittelee toimijuuden relationaaliseksi, eli kaikki toiminta todentuu jonkun/jonkin kanssa, jonkun/jonkin kautta tai jotakin/ jotakuta varten. Kuulemistilaisuudessa ihmistoimijoina ovat kuultava ja kaksi sosiaalityöntekijää. Vuorovaikutuksessaan he rakentavat erilaisia toimijuuksia, kuten instituution toimijuutta, jota sosiaalityöntekijät enemmän edustavat, sekä asianosaisen toimijuutta. Yhdessä he luovat vuorovaikutuksessaan toimijuuden kulttuuria, johon keskeinen ei-inhimillinen toimijuus muotoutuu kirjallisista asiantuntijalausunnoista sosiaalityöntekijöiden laatimista asiakirjoista ja niiden käsittelystä erilaisina viestintätekoina. Tämän toimijuuden kulttuurin tuote ja selkeä lopputulos on kuulemistilaisuuden tuloksena laadittu kuulemispöytäkirja.

Asiakirjojen merkittävyyttä vuorovaikutuksen keskeisenä toimijana korostaa myös se, että niiden lukemiseen kehotettiin usein ja informaation sanoitusta muutettiin, mikäli mahdollista, jos kuultava halusi korjata jotakin tietoa: Äiti: Täällä nyt on semmonen, asiavirhe
mun mielestä tässä sivulla neljä. Et siis täs-
sä sitä että, kun nyt ku meiän lastensuoje-
luasiakkuus alko niin kun X (pvm) ja $Z$
(lapsi) on Y (pvm) poistunut iltamyöhään,
kotoo ni sit täs on et poliisi on molemmilla
kerroilla löytäny Z:n ja palauttanut kotiin
ja molemmilla kerroilla poliisi vei siis tonne,
päivystyspolille.
ST1: Okei.Joo.

Äiti: Ja tosiaan sillon $Y$ (pvm) hän ei, sen jälkeen tullu kotiin vaan meni sinne Lehmuskotiin (nimi muutettu).

ST1:Joo. No ni. Korjaa se, kans sinne. ST2: Joo.

ST1: Tän takia on hyvä että luette huolella kumminki että tulloo ne kaikki oikeet asiavirheet sieltä sitte kans korjattua. (K8)

Toisaalta kuultava saattoi myös itse korostaa ei-inhimillisen toimijuuden valtaa ja luottaa asiakirjojen sisältöön. Näin oli tapahtunut isän kuulemistilaisuudessa, josta kerrottiin äidille hänen kuulemisessaan (K5):

Äiti: Saiko isä lukea myös nää, tämmösen paperin? 
ST1: Sai, mut isä ei lukenu eli me briiffattiin hänelle, hänellä ei ollu silmälaseja mukana.

Äiti: Aa, (tai jos ei sitä) muuten kiinnosta$n u$, niin ku ei tähänkää mennessä kauheesti. ST2: Hän sano, että jos semmone tiivistelmä, ettei tartte kaikkee lukea ihan sanasta sanaan, mutta ST1 (toinen sosiaalityöntekijä) tiivisti siinä kyllä ihan. (K5)

Sosiaalityöntekijän viestintäteko saattoi myös korostaa asiakirjojen ei-inhimillistä toimijuutta esimerkiksi informaation oikeellisuuden osalta:

ST1: Aivan. No nyt meil on siis tavallaan tää virallinen dokumentti mikä tästä nyt täytetään, on tämmönen kuulemiskertomus. Miul on täs kaks kappaletta vaan et jos tulee joku. Ja täs on nyt sitte, katot et siel on siun henkilötiedot kaikki oikein ja X:n (lapsen).

Isä: Tota loppuosaa mä en muista kyllä.

ST1: Se pitäs kyllä olla oikein, ku mie oon vaan kopioinu sen... (K4)

tai suhteuttaa kyseistä toimijuutta sekä osoittaa ymmärrystä ja tukea kuultavalle, kuten seuraava kuvaus osoittaa:

ST2: Tuo on yhteenveto lastensuojelun asiakkuudesta, et se ei oo yhteenveto sun elämästä, vaan se on siitä lastensuojeluasiakkuudesta mikä on sitten koottu meidän asiakirjojen perusteella. (K9)

\section{Pohdinta}

Kuulemistilaisuudessa ratkaistaan inhimillisesti ajatellen suuria lapsen ja huoltajan tulevaisuutta koskevia asioita. Jos huoltaja suostuu huostaanottoon, hän samalla luopuu vapaaehtoisesti keskeisistä lapsen huoltoa koskevista oi- keuksistaan. Myös 12 vuotta täyttänyt lapsi ottaa tahdonilmaisullaan kantaa siihen, kenen arkisessa kasvatuksessa ja missä ympäristössä hän toivoo voivansa varttua lähitulevaisuudessa. Kuulemistilaisuus ei ole neuvottelu, koska keskustelua käydään toisen osapuolen aloitteesta ja keskustelun sisältöä määrittää ei-inhimillinen toimijuus erilaisten kirjallisten dokumenttien muodossa. Asiantuntijuus ja asiantuntijavalta ovat siten läsnä kuulemisessa vahvistaen sen formaalia luonnetta. Kuulemistilaisuudessa keskustelu voisi muodostua korostetun muodolliseksi, jolloin muodollisuus leimaisi myös osapuolten välisiä viestintäsuhteita. Sosiaalityöntekijän ammatilliseen viestintään sisältyy kuitenkin kiinnostavasti niin ammatillisuuteen kuin läheisyyteen kuuluvia elementtejä. Tehtävän hoito käynnistää suhteen, mutta tuttavallisuutta ja välittämistä osoittavat viestintäteot viittaavat suhteen läheisyyteen. Suhteen jatkuvuus ilmenee kaikessa vuorovaikutuksessa näkyen esimerkiksi viestintäteoissa, joilla vedotaan aiempaan tai viitataan tulevaan keskusteluun. Jatkuvuus tekee vuorovaikutuksesta luontevan, koska kohtaamisia on ollut useita ennen kuulemistilaisuutta. Luontevuus taustoittaa myös tuttavallisuutta ja läheisyyttä, koska viestintäkumppanista tiedetään jo jotakin. Näin ollen oman viestintäkäyttäytymisen voi perustaa aiempaan tietoon toisesta. Ensikohtaamisen jännitteitä ei juuri näy. Jännitteitä voi sen sijaan aiheutua kuulemistilaisuuden formaalisuudesta ja siitä, että se on kuultavalle tilanteena uusi.

Se, että tutkitut kuulemistilaisuudet asettuvat osaksi aikaisempien tapaamisten jatkumoa, kertoo huostaanottoratkaisun pitkäkestoisesta 
valmisteluprosessista ja kuultavien ja sosiaalityöntekijöiden välisen suhteen olemassaolosta. Kuulemistilaisuuksien vuorovaikutuksen tarkastelu tuo niin ollen näkyviin sen, että vaikka kuulemistilaisuuksilla on erityinen oikeudellinen ja hallinnollinen tehtävä (asianosaisten mielipiteen selvittäminen), ne toteutetaan tavalla, joka on "tavallinen", ne ovat osa lastensuojelun asiakastyön prosessia. Tämä selittänee sen, että kuulemistilaisuudet järjestetään suullisesti, vaikka lainsäädäntö ei tätä kuulemistapaa edellytä. Kuulemisen kytkeminen asiakastyön tekemisen tapoihin ei ole vain tutkimukseen osallistuneiden kuntien käytäntö, vaan sitä tukee lainsäädännön ohella Terveyden ja hyvinvoinnin laitoksen ylläpitämä Lastensuojelun käsikirja, jonka mukaan kuuleminen voidaan järjestää myös muiden lapsen asioista järjestettävien neuvotteluiden tai läheisneuvonpidon yhteydessä (Asianosaisten kuuleminen 2019) $)^{4}$.

Kuulemisen oikeusturvatehtävä erottaa kuulemisen sosiaalityön tavanomaisesta asiakastyöstä ja tekee siitä tässä mielessä erityisen. Oikeusturvan kannalta tärkeää on huolehtia siitä, että asianosainen saa riittävän ajoissa kaiken sen tiedon, joka voi vaikuttaa annettavaan ratkaisuun. Ilman tätä tietoa hän ei voi muodostaa perusteltua mielipidettä asiaan. Miten kuulemisen oikeusturvatehtävä huostaanoton kohdalla toteutuu, jää aineiston perusteella osaksi avoimeksi kysymykseksi. Aineisto ei kerro tarkasti, mihin kaikkeen informaatioon asianosaiset ovat voineet perehtyä ennen mielipiteen ilmaisua, eikä aina sitäkään, onko perehtymiseen varattu riittävästi aikaa. Osa kuulemisen kohteena olevista asiakirjoista on toimi- tettu asianosaisille etukäteen tai heille on ilmoitettu kuulemiskutsussa, miten asiakirjoihin voi muuten perehtyä.Viitteitä on toisaalta myös siitä, että jossakin tapauksessa yksittäinen asiakirja, esimerkiksi asiantuntijalausunto, on ollut luettavissa vasta kuulemistilaisuudessa. Jälkimmäinen tilanne on pulmallinen sen hallintolain vaatimuksen valossa, että kuulemisaineistoon tutustumiseen on varattava asian laatuun nähden riittävä määräaika. Kysymys voi olla joskus siitä, että asianosaiset eivät ole lukeneet etukäteen saamiaan asiakirjoja niiden kuormittavuuden vuoksi (Vierula 2017) tai että sosiaalityöntekijät pyrkivät tilaisuudessa vielä varmistamaan, että jo aiemmin saatavilla ollut informaatio on asianosaisten tiedossa. Jälkimmäisestä kertoo tilanne, jossa sosiaalityöntekijä lukee ääneen asiakirjan osaa, jota asiakas ei itse pysty lukemaan tai halua lukea.

Kuulemistilaisuudella ei ole institutionaaliselle keskustelulle yleisesti tyypillisï instituution kirjaamia menettelyohjeita. Aineiston perusteella sosiaalityöntekijöiden yhteinen professiotausta, siitä kumpuava ja sitä ylläpitävä viestintä näyttävät yhtenäistävän keskustelun rakennetta ja vaiheistusta eri kunnissa. Vuorovaikutuksen funktiot ja vaiheet ovat samat, mutta sosiaalityöntekijöiden viestintäteot ja osallistujien väliset viestintäsuhteet poikkeavat toisistaan, kuten edellä osoitettiin. Näyttää myös siltä, että kuulemiskeskusteluja sävyttää ammatillinen välittämisen eetos, eikä siksi ole yllättävää, että sosiaalityöntekijän viestintäteot sisältävät niukimmillaankin myönteisiä henkilökeskeisiä suhdesanomia, joilla viestintäkumppani tehdään huomatuksi. Suhdesanoma on suhteen ylläpitoa 
kuvaava sanoma: myönteisillä sanomilla osoitetaan viestintäkumppanille tukea, ymmärrystä tai saman mielisyyttä, kielteisillä sanomilla hänet ohitetaan, ignoroidaan tai suljetaan "ulos" (Hargie 2011).

Kuuntelun osoittaminen tai osoittamattomuus on keskeistä suhdesanomissa. Kuuntelemisen kognitiivinen ulottuvuus on kuulemisessa läsnä esimerkiksi tiedon saamisen ja asian ymmärtämisen kannalta, kun taas kuuntelemisen relationaalinen ulottuvuus erilaisina kuuntelemista osoittavina viestintätekoina vaikuttaa viestintäsuhteisiin. (Bodie ym. 2013.) Kuultavan ja sosiaalityöntekijän kuunteleminen kuulemistilanteessa on olennaista paitsi tiedon saamisen ja prosessoimisen myös läsnä olemisen ja tuen osoittamisen kannalta. Tehokasta kuuntelemista ja havainnointia sosiaalityöntekijä tarvitsee myös työparinsa suhteen, koska kuulemistilaisuuteen ei työparin kanssa ilmeisesti juuri valmistauduta (ks. Loppuviite 1). Kuunteleminen on kuulemistilaisuudessa haasteellista, sillä siinä tarvitaan vaihtelevasti erottelevan (mielipiteet faktoista/johtopäätökset havainnoista) ja yhdistelevän (miten asiat liittyvät toisiinsa) kuuntelun osaamista. Kuunteluosaaminen liittyy ammattiin (Ala-Kortesmaa 2015), ja sosiaalityöntekijän kuunteluosaamisessa yhdistyvät kriittisen ja empaattisen kuuntelun tunnusmerkit.

Oikeuteen tulla kuulluksi sisältyy oikeus kaikkeen siihen tietoon, jota viranomainen voi käyttää päätöksensä perusteena. Hallintolaki tai lastensuojelulaki ei vaadi erikseen viranomaista varmistamaan, että asianosainen ymmärtää asian kannalta merkityksellisen informaation. Käytännössä kuultavan ymmärrystä varmistetaan pitkin koko kuulemisen vuorovaikutusta esimerkiksi sitä suoraan kysymällä tai kysymällä kuultavan käsitystä sosiaalityöntekijän tekemästä yhteenvedosta. Informaation ymmärrettävyys tosin on aina haasteellista vuorovaikutuksessa sen relationaalisen ulottuvuuden vuoksi. Vaikka ymmärrystä rakennetaan vuorovaikutuksessa, vastuu ymmärryksen pohjaksi tarjotusta informaatiosta on lain mukaan viranomaisella. Vastuu korostuu, koska viestintäsuhteiden asymmetrisyys ei tee ilmapiiriltään avoimestakaan vuorovaikutuksesta tasa-arvoista. Näin ollen aiemmin kuvattu sosiaalityöntekijän viestintä, jolla ei estetä kuultavaa osallistumasta tai kysymästä, vaikuttaa tarkoituksenmukaiselta. Kysymiseen ja mielipiteen ilmaisuun rohkaisee myös sosiaalityöntekijän ja kuultavan välisen vuorovaikutuksen korostunut henkilökeskeisyys, joka näkyy kuultavan erilaisena huomioimisena, kuten epäselvyyksien selvittämisenä, informaation kytkemisenä kuultavan kontekstiin ja kuultavan erilaisena tukemisena.

Kriittinen kohta viranomaisen tarjoamassa tiedossa on havainto siitä, että useassa kuulemistilaisuudessa osa huostaanoton oikeudellisia ja muita vaikutuksia koskevasta selvityksestä annetaan ja niistä kysytään vasta sen jälkeen, kun asianosaiset ovat allekirjoittaneet kuulemispöytäkirjan. Aineiston pohjalta ei voida päätellä, onko tällöin kyse lapselle ja vanhemmille kokonaan uudesta selvityksestä vai pyrkivätkö sosiaalityöntekijät vielä kerran varmistamaan, että asianosaiset ovat saaneet kaiken relevantin informaation. Aineisto ei vastaa siihen, mitä tapahtuisi, jos lapsi tai vanhempi kuulemispöytäkirjan alle- 
kirjoitettuaan muuttaisi mielipidettään uuden selvityksen johdosta.

Mielipiteen ilmaisu ei toteudu ilman kuultavan osallistumista. Pohdittavaksi jääkin, onko kysymysten esittäminen ainoa tapata rohkaista osallistumaan vai voiko esimerkiksi ammatillinen läheisyys toimia samoin. Mielipiteen ilmaisu on yksi kuulemistilaisuuden institutionaalisista tavoitteista, eikä tavoite välttämättä toteudu yhdellä $\mathrm{ky}$ symyksellä vaan pikemmin kysymysten ja vastausten sarjalla, jossa kuultavan kompetenssi mielipiteen ilmaisemiseen sekä keskinäiseen vuorovaikutukseen liittyvät emootiot ja jännitteet otetaan huomioon. Aineiston perusteella sosiaalityöntekijät eivät painosta tai ohjaa asianosaisen mielipidettä tiettyyn suuntaan vaan rohkaisevat häntä usealla tavalla ilmaisemaan oman näkemyksensä asiasta.

Oma erityinen kysymyksensä on se, miten kuulemistilaisuudet palvelevat lasten mielipiteen esille tuomista. Aineisto sisältää vain viiden lapsen kuulemisen. Heidän kohdallaan vuorovaikutus ei juuri eronnut aikuisten kanssa tapahtuvasta vuorovaikutuksesta. Ainoastaan asiakirjoja käsiteltäessä tai "rukseja" merkittäessä lasten ymmärrystä pyrittiin erityisesti varmistamaan ja lomakkeen täytön helppoutta perustelemaan. Kuulemistilaisuuteen liittyvät asiakirjat on todettukin varsin aikuisorientoituneiksi (Hoikkala \& Pösö 2019) ja siksi ei ole yllättävää, jos lasten ymmärrystä tuetaan. Tarvitaan lisää tutkimusta sen tarkastelemiseksi, kuinka tarkoituksenmukaista edellä kuvattu viestintä on lasten kannalta.

\section{JоHTOPÄÄTÖKSET}

Kuulemistilaisuus institutionaalisena vuorovaikutuksena pyrkii nimensä ja tehtävänsä mukaisesti selvittämään kuultavan mielipiteen huostaanottoasiassa. Kuulemistilaisuudella on selvä lainsäädännön asettama tehtävä, jota sosiaalityöntekijät toteuttavat osana asiakastyötä. Vuorovaikutustilanteissa on tunnistettavissa jaettuja rakenteita ja asianosaisten mielipiteen ilmaisemisen rohkaisemiseen pyrkiviä viestintätekoja. Asiakirjoihin kirjatulla ja kirjattavalla tiedolla on tilanteissa merkittävä rooli. Se, onko kyse lapsen vai vanhemman kuulemisesta, erottelee vuorovaikutustilanteita vain niukasti.

Tarkastelluissa sosiaalityöntekijöiden, lasten ja vanhempien vuorovaikutustilanteissa mielipiteen vapaata ilmaisua tuettiin. Havainto on tärkeä lisä niihin tutkimuksiin, jotka lähestyvät lastensuojelussa tapahtuvaa mielipiteen ilmaisua lähtökohtaisesti pakotettuna ja sidottuna (esim. Leviner 2017; Lynch \& Boddy 2017). Kriittiset kohdat liittyivät päätöksentekoon vaikuttavan informaation tarjoamisen, mielipiteen ilmaisemisen ja dokumentoinnin ajoituksiin.Vaikka niiden merkitys on tässä aineistossa pieni, ne virittävät kysymyksen siitä, kuinka yleisiä tämänkaltaiset käytännöt ovat. Ei ole tutkimustietoa, jonka pohjalta tähän voitaisiin vastata. Ajankohtaispuheenvuorot vaihtuvista sosiaalityöntekijöistä, asiakassuhteiden pirstaleisuudesta ja suurista asiakasmääristä korostavat joka tapauksessa kysymyksen tärkeyttä. 


\section{Rahoitus}

Artikkeli on osa Suomen Akatemian rahoittamaa tutkimusta "Suostumus ja tahdonvastaisuus lastensuojelun päätöksenteossa: sosio-legaalinen tarkastelu" (308402).

\section{KIITOKSET}

Kirjoittajat haluavat kiittää tutkimuskuntien sosiaalityöntekijöitä ja kuulemistilaisuuksiin osallistuneita vanhempia ja lapsia kuulemistilaisuuksia koskevasta aineistosta. Lisäksi kiitos kuuluu hankkeen laajemmalle tutkimusryhmälle artikkelin aihioiden kommentoinnista.

\section{ViITTEET}

1 Artikkeli on kirjoitettu osana laajempaa, Suomen Akatemian rahoittamaa suostumusta ja vastustusta huostaanottopäätöksenteossa käsittelevää tutkimusta, joka on suunniteltu ja toteutettu yhteistyössä kolmen kunnan lastensuojelun sosiaalityöntekijöiden kanssa. Aineisto koostuu sosiaalityöntekijöiden haastatteluista ja pohdinta-aineistosta, huostaanottoasiakirjoista, kuulemistilaisuuksien taltioinneista sekä asianosaisryhmien kanssa tehdyistä ryhmähaastatteluista. Lisäksi on järjestetty tutkijoiden ja sosiaalityöntekijöiden yhteisiä työpajoja, joissa on käsitelty alustavia tuloksia. Vuonna 2019 järjestetyssä työpajassa käsiteltiin tämän artikkelin analyysia. Keskustelun pohjalta analyysia tarkennettiin.

2 Tietoa ei ole siitä, kuinka moni tutkituista kuulemistilaisuuksista liittyi saman lapsen huostaanottoasiaan. Siksi vastustuksen ilmaisemiseen päätyneiden kuulemistilaisuuksien (vähäistä) osuutta ei ole mahdollista verrata tahdonvastaisten huostaanottojen osuuteen kaikista tilastoiduista huostaanotoista.

3 Aineistonhankinnassa ohjeistettiin so- siaalityöntekijöitä kertomaan tutkimuksesta kuulemistilaisuuksiin tuleville oman harkintansa pohjalta. Tällä haluttiin tukea sitä, että tutkimuskutsua ei tarvinnut esittää tilanteessa, jossa kuultava oli esimerkiksi sairaalahoidossa tai tutkimuskutsu olisi muuten tarpeettomasti kuormittanut kuulemistilaisuuden järjestämistä. Aineiston keruusta neuvoteltaessa sosiaalityöntekijät ennakoivat, että kutsuun tarttuisivat ne, joilla oli joko erittäin kriittinen tai erittäin myötämielinen näkemys huostaanotosta. Työpajoissa käytyjen keskustelujen pohjalta vaikuttaa siltä, että aineistoksi valikoituneet kuulemistilaisuudet eivät ole poikkeuksellisia.

4 Tutkimuksen ns. pohdinta-aineisto-osassa sosiaalityöntekijöitä on pyydetty kertomaan kuulemistilaisuuksien mahdollisesta yllätyksellisyydestä nauhurille välittömästi tilaisuuden jälkeen. Pohdinta-aineisto ei kuitenkaan koske (välttämättä) taltioituja kuulemistilaisuuksia. Aineistosta on saatu käsitystä siitä, miten kuulemistilanne ja mielipiteen esittäminen siinä eroavat muusta lastensuojelun prosessista. Nämä pohdintatallenteet (15) tuovat näkyviin sen, että kuulemistilaisuus ei ole vain jatkumoa edellisille tapaamisille vaan sosiaalityöntekijät pohtivat tilaisuuden vaikutuksia myös tulevaan: miten lapsi asettuu sijaishuoltopaikkaansa, miten vanhempi pitää yllä suhdetta lapseen ja millaiseksi suhde asianosaisten ja sosiaalityöntekijöiden välillä muodostuu jatkossa.

\section{KirjallisuUs}

Ala-Kortesmaa, Sanna (2015) Professional listening in the legal context. Acta Universitatis Tamperensis 2101. Tampere: Tampere University Press.

Asianosaisten kuuleminen (2019) Lastensuojelun käsikirja. https://thl.fi/fi/ web/lastensuojelun-kasikirja/tyoprosessi/huostaanotto/huostaanoton-valmistelu/asianosaisten-kuuleminen Luettu 16.9.2019

Bales, Robert F. (1950) Interaction process analysis. A method for the study of small groups. Cambridge: Addison-Wesley. 
Baxter, Leslie (2010) A dialogic approach to interpersonal/family communication. Teoksessa Donald Carbaugh \& Powell Buzzanell (toim.) Distinctive qualities in communication research. New York: Sage, 13-31.

Bodie, Graham \& Vickery, Andrea J. \& Gearhart, Christopher (2013) The Nature of supportive listening: Exploring the relation between supportive listeners and supportive people. International Journal of Listening 27 (1), 39-49. https://doi.or g/10.1080/10904018.2013.732408

Burleson, Brandt (2009) Understanding the outcomes of supportive communication: A dual-process approach. Journal of Social and Personal Relationships 26 (1), 21-38. https://doi. org/10.1177/0265407509105519

Burns, Kenneth \& Pösö, Tarja \& Skivenes, Marit (2017) (toim.) Child welfare removals by the state: a cross-country analysis of decision-making systems. New York: Oxford University Press. https://doi.org/10.1093/acprof:o so/9780190459567.001.0001

Cooren, Francois (2018) Acting for, with, and through: A relational perspective on agency in MSF's organizing. Teoksessa Bart. M Brummans (toim.) The agency of organizing. Perspectives and case studies. New York: Routledge, 142-169. https:// doi.org/10.4324/9781315622514-7

Craig, Robert (2007) Communication theory as a field. Teoksessa Robert Craig \& Herbert Muller (toim.) Theorizing communication. Readings across traditions. Thousand Oaks CA: Sage, 63-97.

Ervasti, Kaijus \& de Godzinsky,Virve-Maria (2014) Koettu oikeudenmukaisuus tuomioistuimissa. Lakimies 112 (2), 175195.

Galvin, Kathleen \& Cooper, Pamela (2000) Making connections. Readings in relational communication. Los Angeles: Roxbury Publishing Company.

Gerlander, Maija \& Isotalus, Pekka (2010) Professionaalisen viestinnän ääriviivoja. Puhe ja kieli 30 (1), 3-19.

Günther,Kirsi(2015)Asiakasdokumentaatio arviointina mielenterveystyön arjessa: Tutkimus ammatillisesta kirjaamisesta. Acta Universitatis Tamperensis 2108. Tampere:Tampere University Press.
Hall, Christopher \& Juhila, Kirsi \& Matarese, Maureen \& van Nijnatten Carolus (2014) Social work discourse in practice. Teoksessa Christopher Hall, Kirsi Juhila, Maureen Matarese \& Carolus van Nijnatten (toim.) Analysing social work communication: Discourse in practice. London: Routledge, 1-8.

Hargie, Owen (2011) Skilled interpersonal communication. Research, theory and practice. Hove: Routledge. https://doi. org/10.4324/9780203833919

Helavirta, Susanna \& Laakso, Riitta \& Pösö, Tarja (2014) Huostaanoton kuva suomalaisen tutkimuksen valossa. Janus 22 (3), 288-298.

Hoikkala, Susanna \& Pösö,Tarja (2019) The documented layer of children's rights in care order decision-making. Child \& Family Social Work 25 (1), 45-52. https:// doi.org/10.1111/cfs.12711

Kulla, Heikki (2018) Hallintomenettelyn perusteet. Helsinki: Alma Talent.

Laapotti,Tomi (2018) Vuorovaikutus sairaalajohtoryhmien kokouksissa. JYU Dissertations 29. Jyväskylä: Jyväskylän yliopisto.

Lammers, John \& Barbour, Joshua (2006) An institutional theory of organizational communication. Communication Theory 16 (3), 356-377. https://doi. org/10.1111/j.1468-2885.2006.00274.x

Lastensuojelu 2018 (2019) Tilastoraportti 23. Helsinki: Terveyden ja hyvinvoinnin laitos. Suomen virallinen tilasto. http:// urn.fi/URN:NBN:fi-fe2019060418326 Luettu 5.6.2019.

Leviner, Pernilla (2017) Samtyckeskontruktionen I LVU - an analys av gransdragningen mellan frivillighet och tvång, grundantaganden om människans autonomi samt barns begränsade självestämmanderätt. Teoksessa Pernilla Leviner \& Tommy Lundström (toim.) Tvångsvård av barn och unga. Stockholm: Wolters Kluwer, 126-150.

Lonne, Bob \& Harries, Maria \& Featherstone, Brid \& Gray, Mel (2016) Working Ethically in Child Protection. London: Routledge. https://doi. org/10.4324/9781315851020

Lynch, Caroline \& Boddy, Janet (2017) Cooperation or coercion? Children coming into the care system under voluntary ar- 
rangements. https://www.frg.org.uk/ images/YFYV/KI-Report-10.07-final. pdf Luettu 5.5.2019

Mayan, Maria. J. (2009) Essentials of qualitative inquiry. New York: Routledge.

Mäenpää, Olli (2018) Hallinto-oikeus. Helsinki: Alma Talent.

Pearce, Barnett \& Kearney, Jeremy (toim.) (2004) Coordinated management of meaning: innovations and applications. Human Systems 15 (1-3), 1-207.

Pekkarinen, Elina (2016) Toivottu, kiistelty ja torjuttu: lastensuojelun avohuolto huostaanottoasiakirjoissa. Teoksessa Rosi Enroos, Tarja Heino \& Tarja Pösö (toim.) Huostaanotto. Lastensuojelun vativin tehtävä. Tampere:Vastapaino, 103-125.

Pennanen, Eveliina (2018) Hallinnollinen vuorovaikutus sairaalatyöyhteisössä. Jyväskylä Studies in Humanities 340. Jyväskylä: Jyväskylän yliopisto.

Ruusuvuori, Johanna \& Haakana, Markku \& Raevaara, Liisa (2001) Institutionaalinen vuorovaikutus. Keskusteluanalyyttisiä tutkimuksia. Helsinki: Suomalaisen Kirjallisuuden Seura.
Räsänen, Jenni-Mari (2015) Emergency social workers navigating between computer and client. British Journal of Social Work 45 (3), 2106-2123. https://doi. org/10.1093/bjsw/bcu031

Toivonen, Virve \& Pollari, Kirsi (2018) Lapsen haastattelu - osa lapsen oikeutta osallistua. Teoksessa Sauli Hyvärinen \& Tarja Pösö (toim.) Lasten haastattelu lastensuojelussa. Jyväskylä: PS-kustannus, 73-90.

Vierula, Tarja (2017) Lastensuojelun asiakirjat vanhempien näkökulmasta. Acta Universitatis Tamperensis 2323. Tampere: Tampere University Press.

Välikoski, Tuula-Riitta \& Ala-Kortesmaa, Sanna (2014) Suullisuuden periaate vuorovaikutuksen näkökulmasta. Oikeus 43 (2), 192-204.

Välikoski, Tuula-Riitta \& Saranpää, Timo \& Paulanto, Tuulia \& Kulmakorpi, Teemu (2017) Todistajankuulustelukokemus vuorovaikutustilanteena oikeudenmukaisuuden näkökulmasta. Oikeus 3 , 310-322. 